\title{
The (un)suitability of fair-value accounting in emerging economies: The case of Vietnam
}

\author{
Author: Dr Lisa-Uyen Nguyen
}

\begin{abstract}
Purpose - This study explores the suitability and challenges of implementing fair value accounting (FVA) in Vietnam, an emerging/transitioning economy. While such implementation would enable convergence with International Financial Reporting Standards (IFRS), standard setters and auditors have raised practical concerns about its adoption.
\end{abstract}

Design/methodology/approach - This qualitative study utilizes semi-structured interviews with regulators and auditors, together with an analysis of two fraud cases that illustrate the business environment in Vietnam. Public, private, and capture theories guide the analysis.

Findings - The business and institutional environment in Vietnam creates several impediments to FVA being effectively implemented and transparently applied. Given the major challenges identified regarding the infrastructure necessary for this valuation system, the premature adoption of FVA may become a catalyst for corporate misconduct.

Research limitations/implications - The findings are derived from data aggregated from two fraud cases and interviews and, as such, the results may not be generalizable to other settings. However, these findings may inform future research, particularly after the Ministry of Finance provides further guidance on the use of FVA in Vietnam.

Practical implications - A timely and critical examination of the challenges of implementing FVA in a transitioning economy is provided, and the two fraud cases reveal the complexities of the business environment in Vietnam.

Originality/value - This research gives voice to the tensions that developing countries are confronting as they seek to balance external pressures with internal constraints. The introduction of an assemblage of three theoretical lenses enables insights into contemporary issues associated with applying FVA in such settings.

Keywords: Fair value accounting, Vietnam, accounting harmonization, transitioning economy

Paper type: Research paper 


\section{Introduction}

Market globalisation has accelerated the diffusion of International Financial Reporting Standards (IFRS) in both developed and developing countries, revitalising the concept of fair value accounting (FVA) which may be traced back to official pronouncements from the Financial Accounting Standards Board (FASB) in the 1970s (Kumarasiri and Fisher, 2011). As a key measurement base of IFRS, standard setters - encompassing both the International Accounting Standards Board (IASB) and FASB - presume that management can produce estimates of fair values and that auditors can assume responsibility for their verification. The validity of these presumptions have been increasingly challenged within the context of developing countries (Peng and Bewley, 2010; Kumarasiri and Fisher, 2011). Relevance and usefulness, which are the two 'selling' attributes of FVA, might not offset the unintended consequences sometimes ascribed to FVA. In particular, FVA has been accused of exacerbating the severity of financial crises - such as that experienced in 2008 - because it may lead to excessive leverage in boom periods and cause redundant write-down of debts in bust periods (Laux and Leuz, 2009). Managers may also use FVA to manipulate earnings and commit financial reporting fraud (Benston, 2006). ${ }^{1}$

Issues of "Earnings Management and Fraud" raised by a Panel on Audit Effectiveness revealed that "legitimate" and "illegitimate" activities are both subject to earnings management. The "legitimate" methods of earnings management are accounted for "in conformity with generally accepted accounting principles" [GAAP], while the later remain an issue that needs to be dealt with (PCAOB ${ }^{2}, 2000$, chapter 3, 3.15). Barlev and Haddad (2003) lamented that "legitimacy" is claimed simply because of compliance with a given set of GAAP. However, it might still be considered "illegitimate" because the "welfare of the firm's stakeholders" is not necessarily addressed (Barlev and Haddad, 2003, p. 395). Further to Barlev and Haddad's (2003) argument, institutional context plays a substantial role in detecting or giving rise to misconducts (Gabbioneta et al., 2013). Given a somewhat surprising paucity of relevant prior research, this study explores the suitability and challenges of implementing FVA in Vietnam from the perspectives of auditors and standard setters.

Vietnam is an appropriate research setting as it is a developing country transitioning from a centrally planned economy to a market economy. As a part of its commitment to IFRS adoption, in 2015 the government approved Accounting Law No.88/2015/QH13 ${ }^{3}$ (also called Accounting Law 2015) that allows FVA to be embedded in the national accounting system.

\footnotetext{
${ }^{1}$ There are three levels of fair value measurement under IFRS. Level 1 inputs refer to quoted prices of identical assets or liabilities in active markets as at measurement date. Level 2 inputs include quoted prices for similar assets or liabilities in active markets, quoted prices for identical assets or liabilities in inactive markets, and relevant market data. Level 3 inputs refer to circumstances where observable inputs for assets or liabilities are unavailable. In this context, an entity may use the best information available, which may include its own data and all market participant assumptions available, to come up with a fair value (IAS Plus, 2017). Level 1 measures should be the first choice, then level 2, and when these two levels of measurements appear to be inappropriate or unavailable, then level 3 is applied by internal estimate (Benston, 2006). Level 3 is considered the most susceptible to manipulation, being prone to estimate errors and verification difficulties. Investors are unable to discern the magnitude and purpose of the misreporting because of the unobservable managerial manipulation (estimate errors) in determining fair value (Fischer and Verrecchia, 2000). In addition, such estimates enhance managers' opportunities to inflate earnings and hide poor operating performance (Benston et al., 2006). Consequently, shareholders and potential investors would suffer from an array of untrustworthy/"cooked" financial statements as subjective judgements of managers are not easily audited and auditors might cave in to the demands of deceitful managers (Benston et al., 2006).

${ }^{2}$ Public Company Accounting Oversight Board.

${ }^{3}$ Accounting Law No 88/2015/QH13 was enacted on 20 November 2015.
} 
This replaced Accounting Law $2003^{4}$ and constituted a milestone in Vietnamese accounting. With respect to standard setting in Vietnam, IAS ${ }^{5} /$ IFRS have gradually been adopted but with some adjustments to take account of the country's particularities (Nguyen and Nguyen 2012), including the State's exclusive control over the economy through its rule-based systems (Nguyen et al., 2013). This distinctive setting challenges the successful implementation of FVA in Vietnam, as this approach allows a high level of discretion in financial reporting. Therefore, exploring this issue in the context of Vietnam is beneficial for gaining insights into the challenges and struggles that an emerging economy experiences when dealing with such a complicated and controversial standard (Peng and Bewley 2010).

This study adopts a two-stage qualitative approach based on case studies and semi-structured interviews. In the first stage, two fraud cases were selected for analysis: (1) a state-owned enterprise (SOE); and (2) a listed private enterprise. These are used to illustrate the vulnerable and complex economic and political environment in Vietnam. In the second stage, interviews with standard setting officials, partners of Big-4 and second-tier accounting firms and auditors (one audit manager and one senior auditor) were conducted to obtain their perceptions of the challenges and concerns of implementing and applying FVA in Vietnam.

Public interest, private and capture theories were adopted to guide the analysis. Serving the public interest is an underlying principle of public interest theory (original version) and there exists situations in which government interventions reflect their under-performance (reformulated version) (Mitnick, 1980). By contrast, regulatory capture theory highlights regulatory behaviour in which personal interests dominate the regulatory process and resultant policies may not respond to wider societal goals (Levine and Forrence, 1990).

Further to the challenges that prior studies (e.g., Peng and Bewley, 2010; Kumarasiri and Fisher, 2011) have identified, this study contributes to the on-going debate about the implementation of FVA in developing countries, and particularly those with transitioning economies, as a part of the IFRS adoption processes. While such adoption may not substantially change the economic conditions of a nation, it may still be a problematic process due to the heightened risk of earnings manipulation and financial reporting fraud caused by the idiosyncrasies of the national institutional environment. Further, the governments and their agencies might not be able to detect or control such misconduct because of their lack of knowledge and experience in applying IFRS, as well as an over-reliance on auditors as gatekeepers. The findings of this study draw attention to the risks associated with underestimating the impact of institutional context on FVA and are therefore likely to be relevant to both national and international standard setters grappling with the implementation of FVA.

The remainder of this paper is structured as follows. The next section provides a literature review followed by a description of Vietnam's economic and accounting background. This is followed by a discussion of the theoretical framework and research methodology. The research findings are then presented and the paper concludes with a summary of the results and the implications of the findings.

\section{Literature Review}

FVA requires certain assets and liabilities to be (re)valued at fair value to reflect changes in economic value. Under this accounting method, variations from carrying amounts are

4 Accounting Law No 03/2003/QH11 was enacted on 17 June 2003.

5 International Accounting Standards. 
recognised in net income or other comprehensive income for the period. ${ }^{6}$ FVA has received much attention from scholars, practitioners and policy makers because of its complex and controversial nature (Laux and Leuz, 2009; Hodder et al., 2013). There has been considerable debate on the feasibility and superiority of FVA in comparison with historical cost accounting (HCA). By emphasising the relevance and usefulness of fair value to decision-makers, in accordance with the underlying objectives of the financial reporting conceptual framework, many studies conclude that FVA is superior to HCA (Barth et al., 1995; Barth et al., 1996; Aboody et al., 1999). Currently, FVA is widely adopted in accounting standards promulgated by various standard setting bodies, including the FASB and IASB. The pervasiveness of FVA in the financial reporting standards issued by both these standard setters suggests that it has proven to be a feasible measurement basis in developed economies.

However, as a product of its environment, accounting encompasses and reflects the idiosyncrasies of a country's institutional environment (Hopwood, 1983). In this regard, the circumstances of developing countries raise doubts as to the feasibility and superiority of FVA within their specific contexts. A value is considered fair, relevant and useful only when it can be reliably and objectively measured. If not, it could mislead decision makers. Many scholars have claimed that underdeveloped markets, different institutional settings, and low provision of assurance are key factors that hinder the introduction of fair value-based standards (Jermakowicz and Gornik-Tomaszewski, 2006; Peng and Bewley, 2010; Cairns, et al., 2011; Kumarasiri and Fisher, 2011). This is a critical issue for FVA and resulted in a delay in the full adoption of IFRS in the EU (Jermakowicz, 2004; Larson and Street, 2004) and many developing countries (Peng and Bewley, 2010; Qu and Zhang, 2015, Hopper et al., 2016).

Such a delay may be justified on the grounds of preventing the unintended consequences that may accompany FVA. The complexity of this measurement system derives from the variations in model-based measurements used across different industries and the fact that the determination of fair values requires incorporation of future events and their related conditions. Substantial judgements are involved in this valuation process, which leaves room for potential earnings manipulation that national standard setters and auditors may be incapable of detecting (Barth, 1994; Ball, 2006; International Accounting Standard Board (IASB), 2006; Barlev and Haddad, 2007a; Kumarasiri and Fisher, 2011). Given these barriers, the importation and implementation of risky policies such as FVA could be too radical for "fragile developing economies" (Nissanke and Thorbecke, 2006, p. 1338). Even so, the strategic alliance between the IASB and the World Bank has further resulted in significant pressure and concerns for many jurisdictions (Elad, 2007), especially those in which codified laws are instituted and uniform accounting systems have long been a tradition (Elad, 2015).

Peng and Bewley (2010, p. 1007) raise concerns about the appropriateness of uniform FVA standards in developing countries where institutional settings are considerably different from developed economies. While their findings do not support an association between the regulatory violations of several Chinese listed firms and the fraudulent use of FVA, the authors still raised concerns about the reliability of information reported under a FVA regime due to the strong earnings manipulation incentives that inherently exist among Chinese listed firms (Peng and Bewley, 2010). Some factors that triggered their concerns included ineffective oversight mechanisms due to lack of FVA knowledge; reluctance to report and prosecute deficiencies at the nascent stage of FVA implementation; concerns over the impact on the reputation of the Chinese market-based regime; and, a lack of due care from auditors and regulators (Peng and Bewley, 2010). To reduce the risk of earnings management, the Chinese

\footnotetext{
${ }^{6}$ The IASB defines fair value as "the price that would be received to sell an asset or paid to transfer a liability in an orderly transaction between market participants at the measurement date" (IAS Plus, 2017).
} 
government took precautions by restricting the use of fair value in several areas, including debt restructuring and the reversal of asset impairments (Peng and Bewley, 2010). This creates further divergence between Chinese 2007 GAAP and IFRS. The rationale behind such prohibitions is that abnormal gains on debt restructuring are positively associated with earnings manipulation incentives. Moreover, these associations are more pronounced in firms that have a high level of political connections as well as arm's length transactions (He et al., 2012). The case of China highlights the risk of misconduct in institutional environments in which political intervention by the State and its agencies is high.

While external pressures are exerted on developing countries to adopt IFRS-FVA, internal challenges over the implications and consequences seem to exacerbate tensions that outsiders may know little about. Although prior studies have identified some challenges that developing countries encounter when implementing FVA, little attention has been given to how it may precipitate corporate wrongdoings. This study extends prior studies (He et al., 2012; Peng and Bewley, 2010) by investigating the challenges that developing countries face when implementing FVA, while also paying attention to the inherent political risks, as suggested by the case of China. Vietnam was selected for this study as it is also a transitioning economy like China. The literature suggests that institutional settings and political and economic factors vary by country (Cairns et al., 2011; Jermakowicz and Gornik-Tomaszewski, 2006; Kumarasiri and Fisher, 2011) and are often associated with corporate illegalities. In other words, illegality is more likely to occur when individuals and corporations are able to make use of regulatory loopholes to conceal their illegal actions (Gabbioneta et al., 2013) and this is accentuated by over-reliance upon, and/or the over-confidence of, professional regulators and auditors. Their judgements and critical assessments are often compromised, in particular, when they come to assess high status or 'celebrity' organizations (Gabbioneta et al., 2013). A privileged status could be recognised, for example, when an organization joins a network of elite organizations (Gabbioneta et al., 2013). These influential networks of organizations vary by country and are often politically backed in contexts where the State's control and intervention are significant. As connections or collusions represent the 'dark side' of organizations (Vaughan, 1999) and are 'sadly commonplace' in some institutional contexts (Shadnam \& Lawrence, 2011), the incompetency of gate-keepers - that is, regulators and auditors - might further make these environments unfavourable for subjective accounting concepts like FVA.

While FVA itself may be superior to historical cost accounting and provide the preferred measurement base for a range of assets and liabilities (Barth and Clinch, 1996; Barlev and Haddad, 2007b), degrees of earnings manipulation and concealment are dependent on the institutional context of each country. That is, this context determines the extent to which the advantages (or disadvantages) of FVA may manifest. Al-Yaseen and Al-Khadash (2011) claim a higher degree of volatility and risk exist when income recognition is based on fair value rather than historical cost. Elleuch and Taktak (2015) also contend that the risk of earnings management is accentuated under FVA, even when regulations seek to impose restrictions on managerial discretions.

By focussing on a country's institutional context, this study seeks to augment understanding of the challenges that transitioning economies might be struggling with, especially when national institutional environments may accentuate the risks of misconduct. Two research questions are addressed in this study:

$R Q 1$. Is Vietnam's institutional environment favourable or unfavourable to FVA, and why? 
$R Q 2$. What are the challenges to FVA implementation identified by standard setters and external auditors?

The following section provides an important "entrance" to understanding the dynamics of accounting practice and regulation in Vietnam.

\section{Vietnamese Institutional Setting}

Throughout its history, Vietnam had experienced several invasions - from China, France and the US - and it had often been involved in wars. As Taylor (1983, p.18) commented: "No theme is more consistent in Vietnamese history than the theme of resistance to foreign aggression". Since 1975, the Communist Party has ruled the country and imposed a Sovietstyle command economy. The State controlled all aspects of economic activity, mainly through various forms of state and collective ownerships (Van Arkadie, 2003). In 1986, the $6^{\text {th }}$ National Congress of the Communist Party of Vietnam marked the inception of a period of economic reform with the adoption of the "doi moi" (Open-door) policy, signalling a move from a central command to a socialist-oriented market economy. A certain level of decentralisation of economic planning has been instituted, and market forces, to some extent, have been accepted as the determinants of prices and production (Anderson-Gough et al., 2005). The new economic system, via the doi moi policy, has brought about exceptional changes to the socioeconomic environment (Nguyen and Richard, 2011), including: reduced barriers to foreign investment; participation in regional and international trading systems; isolation of commercial banking operations from the State Bank; and a more market-oriented determination of the foreign exchange rate system (Nguyen and Richard, 2011). Private sector economic activity was also permitted and legally backed by the private enterprise law issued in 1990 (Hakkala and Kokko, 2007).

While the socialist-oriented market economy is based on some underlying principles and rules of a market economy, it also retains socialist characteristics. Ownership, appointment of management, and organization of resource distribution generally remain under the control of the Communist Party (Vietnam Law, 2015), with these three characteristics embedded in the State's strategic economic reforms. Several SOEs were reformed/equitized ${ }^{7}$ to become either limited liability entities, with the State as sole owner, or joint-stock companies. In many large joint-stock companies, internal managers, employees and the State hold the majority of shares. In 2017, Vietnam had 505 companies with 100 percent state-ownership and approximately 2,000 SOEs in which the state had a majority interest (Bureau of Economic and Business Affairs, 2018). This mechanism was aimed at preserving the State's control, enabling it to strategically resist external pressures from investors (Beresford, 2008). Within this structure, there is not a clear separation between ownership and management. This concentrated ownership is also perceived to influence the operation of equitized SOEs, with managers who are appointed by the State often seeking advice from controlling governmental entities on daily operational matters (Gainsborough, 2009). Consequently, accountability disclosures are often perceived as being unnecessary. As Vu (2012, p. 233) explains: "State ownership represents no 'real owner' and as such, there is lack of 'real incentive' [for the State] to monitor firms, thereby giving firms little motivation to disclose more information". While government Decree $81 / 2015 /$ ND-CP, issued in 2015, requires SOEs to comply strictly with disclosure requirements

\footnotetext{
${ }^{7}$ In 1992, an initial equitization program was implemented following Decree No. 388/HDBT - Government of Vietnam.
} 
for listed companies, compliance was limited due to inadequate enforcement and unclear punishment for violations (Bureau of Economic and Business Affairs, 2018).

The World Bank (2006) raised a concern about assurance on the quality of disclosed information, which may or may not comply with the Vietnamese Accounting Standards and/or IAS/IFRS. This concern derives from the fact that Vietnam does not have an efficient enforcing mechanism and quality review process (World Bank, 2006). This casts doubt on the quality of information disclosed. In recent years, the World Bank has debarred and blacklisted a number of companies in Vietnam due to fraudulent activities and collusive practices. In 2015, the World Bank debarred SFC Vietnam Investment Development for Environment Corporation and its affiliates for a minimum of 10 years. The company's General Director, Mr. Nguyen Phuong Quy, and any entity that he directly or indirectly controls were debarred for a minimum of 11 years (World Bank, 2015). In the case of Vietnam Inland Waterways Administration, the World Bank also blacklisted executives of Minh Anh JSC., An Hoa Co., Ltd., and Thang Loi Group Co., Ltd for committing fraud by submitting misrepresented documents, including company capacity profiles and the falsification (overstatement) of the contracts when bidding for construction contracts under projects WB5 and WB6. The falsified documents passed the officials because they were too complex to understand and detect (Vietnam Investment Review, 2017a). In a World Bank funded road project (in 2017), two contractors were also banned for fraud, including declaration of overstated revenue in order to eligibility for bidding (Vietnam Investment Review, 2017b).

Misconducts discovered by the World Bank have further shaken the confidence of investors and the general public about business practice in Vietnam. A Vietnamese court is set to make a key ruling in the country's biggest-ever fraud case, involving the theft of 4.9 trillion VND (\$215 million USD) from the state-controlled VietinBank, with the perpetrator already sentenced to life imprisonment. Court documents showed that Huynh Thi Huyen Nhu and accomplices were convicted in 2014 for misappropriation of funds from 15 victims in the period 2010-2011. Fake documents were used to appropriate the funds (Pearson, 2018). During the period, 2011-2016, State auditors and inspectors further executed 19 investigations in SOEs and discovered many regulatory violations in association with the scope and decision-making pertaining to investments and purchases of assets, accounting for up to 345,869 billion VND (48.3 million USD). The State could only retrieve 1,038 billion VND. Further investigation was made of 16 cases and 17 individuals (Cafef, 2018).

In the case of the state-owned bank BIDV (Bank for Investment and Development of Vietnam), and VNCB (Vietnam Construction Bank), a massive fraud case was also discovered. Due to inadequate equity, Pham Cong Danh (former chairman of VNCB) approached BIDV to introduce some corporate clients that were actually owned by Danh. Falsified financial documents were prepared for submission to BIDV. The former chairman of BIDV (Tran Bac Ha) had allowed these 12 companies to borrow 4.7 trillion VND (206 million USD) (Vnexpress, 2018). His argument was that approval was made due to referral from Danh, and he declared that he had known nothing about Pham Cong Danh's ownership of these companies (Dan Tri, 2018a). This money was deposited to VNCB for rising opening equity that was then rejected by the Central Bank. Ultimately, this money was nowhere to be found. Similarly, the former chairman of Sacombank allowed VNCB to borrow 1.8 trillion VND without going through credit procedures (Dan Tri, 2018b). This was a complex fraud case involving many leaders in the business community and banks, as well as Communist Party members. As a result of all these complex transactions, Pham Cong Danh was prosecuted for stealing 9 trillion VND (\$394 million USD) and sentenced for 30 years in prison. State inspectors also found that the 
Party's standing committee at BIDV during the periods of 2010-2015 and 2015-2020 had violated the democratic centralism principle, showed lack of responsibility, poor leadership and a lack of inspection and supervision. Tran Bac Ha's behaviour caused damage to the Party and BIDV and resulted in several staff members being criminally prosecuted. Therefore, he merited disciplinary action (Vnexpress, 2018). According to Centre For Social Governance Research (2017), businesses believe that regulatory loopholes causes rent-seeking and facilitation payments, which have become common. Accordingly, the institutional environment in Vietnam triggers major concerns over accounting practice and the quality of the reporting system.

In Vietnam, the Uniform Accounting System (UAS) is the key source of accounting policies reflecting the country's central plans and consists four key aspects:

- a strictly prescribed chart of account names and numbers;

- detailed guidance of accounting treatments, particularly journal entries applicable to various economic transactions;

- rigid requirements for accounting documents; and

- prescribed formats for financial statements.

The first UAS was developed via Decision 1141 in 1995 and is applicable to all sectors (Article 9) (Vietnamese National Assembly, 2003). However, within each sector the corresponding minister is responsible for further developing the UAS, i.e., Decision 1141, to reflect the nature of the sector. At the national level, the UAS has been regularly updated to accommodate changes in the nation's growing economy.

In 1998, an accounting harmonization program ${ }^{8}$ was initiated with financial support from the Asian Development Bank and the World Bank (Narayan and Godden, 2000). As the national standard setter, the Department of Accounting and Auditing Policy (DAAP) ${ }^{9}$ (a department within the Ministry of Finance) issued 26 accounting standards called Vietnamese Accounting Standards (VAS), which are mainly based on the old IAS. The historical development of accounting practice in the country reveals a mandatory rule-based accounting system predominantly through the operation of the UAS (Decision 1141 - in 1995; Decision 15 - in 2006; Circular 200 - in 2014). ${ }^{10}$ In 2015, the government issued of Accounting Law 2015 (No.88/2015/QH13). While considered a milestone for Vietnam in its transition to IFRS as it

\footnotetext{
${ }^{8}$ In the period 1994-1995, the World Bank, Asian Development Bank and International Monetary Fund (IMF) agreed to provide Vietnam with financial support. However, approval for funding was subject to Vietnam having a clearly defined legal system, including appropriate accounting law and accounting and auditing standards. Progress in accounting system development, or at least a general plan on how it would be undertaken, was expected (Chu, 2004).

${ }^{9}$ In response to Decision 1503/1998/QD-BTC issued on 30 October 1998, the Vietnamese Accounting Standards Committee (VASC) was established and its responsibilities were to monitor the researching and drafting national of accounting standards with a deadline for completion of 2003. Other departments were called upon to assist the DAAP, including the General Department of Taxation, State Budget Department, State Treasury, Financial Policy Department, Corporate Finance Department, and the Investment Department. These departments had to appoint officials to support the VASC. Furthermore, Decision 38/QD-BTC 14/3/2000 specified some guiding principles for the development of the Vietnamese accounting and auditing standards.

${ }^{10}$ Based on the VAS, the UAS was continuously updated through Decision No. 15/2006/QD-BTC "Enterprise Accounting System". In December 2014, it was again revamped to accommodate some of the latest IAS/IFRS via Circular No. 200/2014/TT-BTC “Guidelines for accounting policies for enterprises”. Given the absence of legal backing for FVA, the Circular 200 did not have detailed guidance on measurement of assets and liabilities using FVA.
} 
allows fair value concept to be issued, the fair value application rises more concerns than its potential benefits.

Within this institutional environment, the high level of discretion given is closely associated with a high risk of financial misconduct - which the State and its agencies might not be capable of controlling (Nguyen et al., 2013). According to a member of the State Securities Commission of Vietnam, the common issues in public companies' financial statements are limited disclosures, and inadequate verification of cash, inventory and fixed assets on hand (Dau Tu Chung Khoan, 2017). Further, the Vice President of the DAAP, Mr Trinh Duc Vinh, stated that unintentional errors are often not very material nor easily discovered (Dau Tu Chung Khoan, 2017). By contrast, intentional manipulations are difficult to identify and prone to have serious impact. A Director of Deloitte Vietnam, Mr Nguyen Tuan Anh, further highlights that incorrectly presented and inadequately disclosed material information in the financial statements is a weakness of many listed companies' accounts (Dau Tu Chung Khoan, 2017). In 2015, Accounting Law 2015 was passed, which provides legal backing for future standards using the fair-value concept. The promulgation of this accounting concept in the context of a transitioning economy presents several challenges and conflicts. The theoretical underpinnings of conflict between public and private interests is discussed in the following section.

\section{Theoretical framework}

The accounting standard setting process is viewed as a dynamic political activity that accentuates the constituent support of the State, the accounting profession's expertise, and nonaccountant representatives (Tower, 1993). The coercive power of the State and its substantial intervention are not a new phenomenon in many developing countries and has been regarded as necessary to safeguard the public interest and maintain uniformity (Perera, 1989). Regulation, via the lens of public interest theory, is perceived as a mechanism of improving societal welfare. In particular, under this perspective, protecting the public interest is seen as the primary purpose of regulation (Peirson and Ramsay, 1983); for example, by rectifying market imperfections such as monopoly power (Tower, 1993). Public interest theory comprises two versions: the original and a reformulated version (Posner, 1974, pp. 336-337).

The original version of public interest theory considers that "regulation is supplied in response to the demand of the public for the correction of inefficient or inequitable market practices" (Posner, 1974, p. 335). This version of public interest theory highlights the positive role of government in tackling market failure or crisis. For example, in Australia, responsibility for the development of accounting standards was removed from the professional accounting bodies and transferred to government and given the force of law by the establishment of the Accounting Standards Review Board (ASRB) in 1984. This transfer of responsibility for developing accounting standards occurred after the Australian accounting profession was blamed for promulgating poor quality accounting standards and overseeing low levels of compliance (Walker, 1987; Chalmers et al., 2012). Similarly, serving the public interest by harmonising to international accounting standards has provided a motivation for world-wide calls for harmonization (Collett et al., 2001).

Perera (1989) contends that developing countries should not be encouraged to adopt accounting principles and practices deriving from Western capitalist countries. Due to the idiosyncrasies of developing countries and the skills available within them, foreign principles and practice may be irrelevant and harmful to developing countries in the long run. For these reasons, he 
urges that a government body should regulate accounting practice to best serve the public interest and provide adequate supervision on their compliance. Further, Choi and Mueller (1992) believe that in the environment of developing countries, the public interest is best served if business enterprise accounting is well connected with national economic policies (p. 46). Accounting is not aimed solely at serving the functioning of capital markets; it can also be a tool connecting macroeconomic policies with broad national economic goals (Perera, 1989).

In contrast with the original version, the reformulated version of public interest theory emphasises the negative aspects of government intervention. Deriving from the core concept of public interest that acknowledges the bona fide incentives of regulatory institutions, the reformulated version highlights inefficacies in the performance of government agencies. Three possible explanations for this are: (1) regulators are or become venal (evil); (2) regulators are or become incompetent; and (3) regulation becomes captured by the regulated interest group (Mitnick, 1980, p. 94). To a certain extent, the deviation of the reformulated version of public interest theory is instigated by the private interests of office holders.

Historically, governmental policy-makers have perceived themselves as "public servants" or "civil servants" and claimed to be serving the public interest. However, this view has been challenged and cynically perceived as being naïve, given that personal interests are inherently inescapable (Levine and Forrence, 1990). It is not uncommon for regulators to obtain personal benefits from their office holding, seek pecuniary opportunities in post-governmental employment, or gain personal benefits from an array of private individuals (Downs, 1957, 1967), as is suggested by the private interest theory (Gaffikin, 2005).

Derived from the reformulated version of public interest theory, regulatory capture theory outlines a form of government failure that occurs when a regulatory agency, created to act in the public interest, becomes dominated by the industries it was charged with regulating. For example, where the accounting profession dominates a regulatory agency that was established to develop accounting standards. It is a specific form of private interest theory that accentuates circumstances in which individuals or parties likely to be adversely affected by legislation or regulations use political influence to lobby outcomes for their benefits (Chalmers et al., 2012). Although a regulation might aim to protect the public interest, regulated individuals are still able to lobby to advance their personal interest (Peltzman, 1976). Regulatory behaviour is central to regulatory capture theory in which personal interest influences the regulatory process. Levine and Forrence (1990, p. 169) explain: "personal goods are acquired or cemented by using regulatory power to help others achieve similarly narrow goals, often pecuniary, in the course of which the whole process gives only lip service (or maybe "tiebreaking" recognition) to broader societal goals."

Further to the aforementioned establishment of the ASRB that was expected to be an independent board protecting the public interest, Walker (1987) argued that this board was not entirely independent for it was captured or influenced by the accounting profession. More globally, the increasing adoption of IAS/IFRS raises concerns about the International Accounting Standard Board's (IASB) independence because the standard setting process was believed to be influenced by powerful interest groups. Coordination between the IASB and FASB in an amendment of IAS 39 has been offered as evidence that the IASB was captured by powerful private interest groups, with its accounting standards ascribed to be a catalyst of the global financial crisis (Chalmers et al., 2012).

For the purpose of this study, public interest, private interest and regulatory capture theories are employed to analyse the heterogeneous setting in Vietnam and the ways in which it may exacerbate the risk of financial reporting manipulations. 


\section{Research methodology}

Two research questions are addressed in this study: (1) Is Vietnam's institutional environment favourable or unfavourable to FVA, and why?; (2) What are the challenges to FVA implementation identified by standard setters and external auditors? To address these research questions, both primary and secondary data were collected.

\section{Data collection}

First, secondary data were collected for two fraud cases: (1) Vinashin - a large state-owned shipbuilding Industry Corporation; and (2) Truong Thanh Furniture Corporation (TTF) - a listed private company. These two cases were selected among many similar cases in both SOEs and non-SOEs. The rationale behind the inclusion of these two cases in this study was to illustrate the risk of regulations being disabled/violated by both the Government and auditors who are expected to safeguard the public interest. Data related to these two cases were collected from publicly available domains both in Vietnamese and international websites, with the aim of revealing the complexity and vulnerability of the country's business environment and national institutional setting and which may affect the application of FVA. To ensure the stories of the two cases were published consistently on public media, the author visited various websites to obtain confirmatory evidence. Secondary data in the form of accounting regulations, such as accounting laws 2003, 2015, circular 200 and circular 201, as well as Criminal Law were also employed in this study. In addition, World Bank reports and publicly available documents were consulted in order to supplement and triangulate the information obtained through interviews.

Second, primary data in the form of 12 semi-structured interviews with regulators, partners of Big-4 and second-tier accounting firms and auditors (one audit manager and one audit senior) were conducted. The interviews were designed to explore the understandings and perceptions of standard setters and auditors about the challenges and concerns of implementing and applying FVA in Vietnam and possible strategies to alleviate these issues.

The interviews were conducted in two main cities of Vietnam: Ho Chi Minh City and Hanoi. The interviewees were selected for their influential roles and experience in the areas subject to investigation in this study. The interviewees' profiles are shown in Table 1. For confidentiality purposes, each interviewee was coded by a random number assigned by the researcher (e.g., REG, 1 means Regulator, number 1).

\begin{tabular}{|l|l|l|}
\hline Description & Abbreviation & $\begin{array}{l}\text { Interview duration } \\
\text { (minutes) }\end{array}$ \\
\hline Regulator & REG, 1 & 90 \\
\hline Regulator & REG, 2 & 90 \\
\hline Big-Four audit partner (KPMG) & PB4, 3 & 54 \\
\hline Big-Four audit partner (Deloitte) & PB4, 4 & 50 \\
\hline Big-Four audit partner (EY) & PB4, 5 & 49 \\
\hline Big-Four audit partner (PwC) & PB4, 6 & 70 \\
\hline Big-Four tax partner (Deloitte) & PB4, 7 & 74 \\
\hline Audit partner - 2 $2^{\text {nd }}$ tier firm & $2^{\text {nd }} \mathrm{P}, 8$ & 70 \\
\hline Audit partner $-2^{\text {nd }}$ tier firm & $2^{\text {nd }} \mathrm{P}, 9$ & 75 \\
\hline
\end{tabular}




\begin{tabular}{|l|l|l|}
\hline Audit partner $-2^{\text {nd }}$ tier firm & $2^{\text {nd }} \mathrm{P}, 10$ & 60 \\
\hline Audit manager $(\mathrm{BDO})$ & $\mathrm{A}, 11$ & 60 \\
\hline Senior auditor & $\mathrm{A}, 12$ & 45 \\
\hline
\end{tabular}

Table 1: Interviewee profiles

The participants who are senior partners in Big-4 firms and senior auditors in second-tier firms were selected for their influential experience and in-depth knowledge of accounting and auditing practice in Vietnam. Regulators are key standard setters and have been in the position for many years. The researcher was introduced to these high-profile individuals through personal contacts in the researcher's network. Snow-balling was applied (Patton, 2002). Interviewees were contacted via email for confirmation of their participation. Most of interviewees could not fix the date too far in advance and often requested the researcher to call them when she arrived in Vietnam. The time and location of the interviews were then decided by interviewees. Coffee shops and offices were two locations that interviewees preferred. The researcher was flexible in prioritising the comfort and preferences of the interviewees.

At the start of each interview, the participants were given a consent form to sign and asked for permission to record the interview by a digital recorder. If a participant indicated even slight hesitation about being recorded, the researcher took handwritten notes instead of recording the interview. To overcome the negative aspects of formal interviews, the researcher attempted to create a friendly atmosphere by starting each interview with an informal conversation before starting the first interview question. As suggested by Rubin and Rubin (2005), to become a good interviewer a researcher has to know how to undertake an informal conversation, which is then compensated for by the wealth of data gathered. Ultimately, four interviews were digitally recorded and the eight remaining interviews were subject to note-taking. After each of the eight interviews, the researcher rewrote a full draft of the interview content while it was still fresh (no later than three hours after the interviews). All interviews and the majority of documents were in Vietnamese. The presented quotations were translated to English by the author.

\section{Data analysis}

The analysis of transcripts and materials of the two cases were undertaken using traditional narrative, thematic analysis (Flick, 2014). No formal coding software was used. Instead, the analysis was guided by the theoretical concepts outlined in the previous section, which focused on how public and private interests theoretical lenses were executed in the country.

The author first conducted repeated reading, comparing and assessing the interview transcripts, seeking patterns responding to research question 2 that highlight practical impediments and challenges of FVA implementation. As informed by the relevant literature, FVA is a debateable concept and requires extensive disclosures and managerial judgments, which may not be compatible with the typical institutional setting and business environment of the country. In particular, the author focussed on understanding the role of the State and auditors in both SOEs and private enterprises. Moreover, attention was also given to misconduct arising in the nominated companies that exclusively attracted public attention and constituted social issues. There might have been some political factors involved in these cases to which the author had no access. Despite this limitation, the author believed that the cases on hand, via publically available information, adequately illustrate the complexity of the business environment and 
further clarified some of the challenges and failures that Vietnam's economy has been facing since the doi moi policy was instituted in 1986.

The next step was a coordination of these themes to respond to the research questions (Ryan et $a l ., 2003$, Berry and Otley, 2004). Both the cases and interviews revealed conflicts and struggles that regulators and auditors have been facing and further shed light on the (un)suitability of FVA in the institutional / business environment in Vietnam. These two sources of data interplayed in pursuit of the study's objective to determine whether the process of adopting and implementing IAS/IFRS is problematic in developing countries and whether the institutional context is (un)favourable to FVA. The findings from the two cases are presented first to respond to research question one. The response to research question two is followed by the themes derived from the interviews.

\section{Is Vietnam's institutional environment favourable or unfavourable to FVA, and why?}

\section{Vinashin - Shipbuilding Industry Corporation}

In 2005, adopting Japan's Keiretsus model, State Economic Groups (SEG) were established to loosely connect SOEs with similar business interests and allow decentralisation to local governments before the country was admitted to World Trade Organization (WTO) in 2007. This event triggered an unprecedented inflow of private external capital, which accounted for 18\% of GDP in 2007 (World Bank, 2012).

Vinashin Shipbuilding Industry Corporation was one of the largest SEGs with 160 subsidiaries and 70,000 employees. Its core businesses were ship-building, ship-repairing, shipping, heavy industry and other related services (World Bank, 2012). With strong State support to access loans, Vinashin invested in various non-core business activities such as real estate, securities, and tourism. It ended up with about US\$4.4 billion in debt, which was equivalent to $5 \%$ of Vietnam's GDP in 2009. Vinashin made many questionable investments; for example, it took a huge loan to purchase an extremely expensive (about US\$61 million) but obsolete shipyard. No formal valuations and approvals were undertaken for this investment (Tuoi Tre, 2010). Investors, foreign banks, and taxpayers were worried Vinashin would default on its debts as they held US\$187 million in bonds and US\$600 million in outstanding loans. There was also a concern that taxpayers would need to foot the bill if Vinashin defaulted on its debts. $\mathrm{Mr}$ Nguyen Hong Truong, the deputy transport minister, stated: "If banks cannot provide enough credit, the government will issue new bonds [to meet the company's obligations]" (Jeffries, 2010 , p. 7). This statement by the government official implicitly confirmed a common practice in Vietnam: that Government will bail out companies where there is a government-interest involved.

The default of Vinashin threatened the country's economy, causing a downgrade in the credit rating of the country by Moody's and Standard and Poor's. The government had to provide financial support to Vinashin in the form of interest-free loans so that it could pay salaries to employees (The Guardian, 2011). As part of its efforts to save Vinashin, the Government allowed many commercial banks (e.g., Habubank, Oceanbank etc.) that had provided loans to Vinashin to not make bad debt provisions for the loans to Vinashin (Vietnamnet, 2012). In other words, without going through credit assessment, these banks were encouraged to lend more to Vinashin. In the 2011 annual report of Oceanbank, the Deloitte audit opinion reveals:

On 31.12.2011, the bank (Oceanbank) held deposits, loans, bond investments in Vietnam Shipbuilding Industry (Vinashin) and a few companies owned by Vinashin that were overdue. However, in 2011, according to a written direction of the State 
regulators about reconsideration and restructure of the debts of Vinashin, the bank has followed the directive by keeping the existing debts unchanged and no provision was made for the debts to be due to collect. Currently, the bank is working with Vinashin and the State regulators on how to tackle the debts. (Vietnamnet, 2012)

State intervention has implicitly become a "common practice" in Vietnam protecting the interests of officeholders while potentially undermining regulations (e.g., prescribed commercial banks not to conduct credit risk assessment and make a provision for bad debts). This partly reflects a finding from Nguyen et al's (2013) study: "The Government establishes policy of rules [rule-based uniform accounting system] to assert their benefits. I understand that whoever comes to the 'throne', new regulations would then be issued to protect their patron's power" (p. 478). Government support or protection might have contributed to manipulation of the financial statements as revealed in the quotation below:

In many years, Vinashin had provided falsified financial reports. In 2009, the loss was 1,600 billion VND but Vinashin reported a profit of 750 billion VND. The first quarter of 2010, profit of 100 billion VND was, again, reported instead of its actual loss. This misconduct of Vinashin management failed to alert the Government so that timely guidance or prescriptions could have made. (Thanh nien, 2010, paragraph 8)

Further, managerial discretion had resulted in misconduct in the evaluation of assets and in making projections, which led to huge debts. The entity established more than 200 subsidiaries outside its core-business operations. The Chairman seriously infringed regulations on the management and usage of state-capital (World Bank, 2012). The World Bank concluded that limited transparency, a lack of accountability, ineffective internal control, no independent external audits and the excessive power of senior management were key factors leading to the failure of Vinashin (World Bank, 2012). In fact, these factors are crucial for FVA to be transparently applied, for this accounting measurement entails a great deal of managerial discretion that needs to be balanced by disclosure and supervision.

Further, the Criminal Law 1999, Article 285 states that a loss in value of a State asset could result in a criminal prosecution of the members of the governing body and senior management. This course of action may be best served in the case of fraud, misappropriation of assets or misconduct of management. Under this law, former CEO, Tran Van Liem, and former sales managers, Giang Kim Dat, were prosecuted and received death sentences on embezzlement charges. Former chief accountant, Tran Van Khuong, was sentenced to life in jail for misappropriation of assets (Vnexpress, 2017). Former chairman and general director, Pham Thanh Binh, was sentenced to 20 years in prison for deliberately violating the State's regulations, resulting in a substantial loss (Tuoi Tre, 2017). A major concern was that while at least 11 inspections and audits occurred in the period 2006-2009, as outlined below, no misconduct was reported.

\begin{tabular}{|c|c|c|}
\hline Year & $\begin{array}{l}\text { State agencies and independent external } \\
\text { audit firm }\end{array}$ & Reasons \\
\hline 2006 & $\begin{array}{l}\text { (1) Ministry of Finance } \\
\text { (2) KPMG }\end{array}$ & $\begin{array}{l}\text { (1) Inspecting governance and } \\
\text { usage of international bonds } \\
\text { (2) Auditing financial statements }\end{array}$ \\
\hline 2007 & $\begin{array}{l}\text { (1) Ministry of Construction } \\
\text { (2) KPMG }\end{array}$ & $\begin{array}{l}\text { (1) Inspecting the financial } \\
\text { management } \\
\text { (2) Auditing financial statements }\end{array}$ \\
\hline
\end{tabular}




\begin{tabular}{|l|l|l|}
\hline 2008 & $\begin{array}{l}\text { (1) Ministry of Finance } \\
\text { (2) Ministry of Planning and }\end{array}$ & $\begin{array}{l}\text { (1) Inspecting } \\
\text { management }\end{array}$ \\
& $\begin{array}{l}\text { (2) Investment } \\
\text { (3) Supervision delegation from } \\
\text { National Assembly Standing } \\
\text { Committee }\end{array}$ & $\begin{array}{l}\text { (3) Inspecting compliance to } \\
\text { regulatory policy of investment, } \\
\text { construction and usage of state } \\
\text { capital }\end{array}$ \\
& $\begin{array}{l}\text { (4) Government Inspectorate } \\
\text { (5) KPMG }\end{array}$ & $\begin{array}{l}\text { (4) Inspecting construction project, } \\
\text { purchases of equipment for key } \\
\text { laboratory rooms; and ship } \\
\text { model test tank }\end{array}$ \\
& \begin{tabular}{l} 
(5) Auditing financial statements \\
\hline 2009
\end{tabular} \\
(1) Ministry of Finance & (1) Inspecting governance and \\
(2) KPMG & (2) Auditing financial statements \\
\hline
\end{tabular}

Table 2: State inspections and independent audits during the period of 2006-2009 (adapted from (Lao dong, 2010)

Lao dong (2010) raises concerns about whether these 11 inspections and audits were appropriately conducted or whether senior management concealed the fraud so well that it was not uncovered, or whether the auditors and inspectors lacked professional scepticism due to Vinashin's ‘celebrity' status.

\section{Truong Thanh Furniture Corporation (TTF)}

TTF was founded in 1993 and became one of the most successful pioneers in the wood processing industry in Vietnam. With eight factories and 6,500 employees, TTF produced indoor furniture, outdoor furniture, floorings, decking, tile, doors, etc. supplying national and international markets, such as the USA, Europe and Japan (Truong Thanh, 2017).

In 2016, investors were shocked when TTF reported a loss of 1,100 billion VND in the second quarter 2016 (US $\$ 50$ million). This figure was adjusted by the international audit firm Ernst and Young to reflect non-existent inventory that had been included on the audited balance sheet and 227 billion VND (US \$10million) of provision for doubtful debts that TFF failed to reflect in its audited financial statements. Importantly, a clean audit report was issued by audit firm DFK for the year ended 2015 (Cafef, 2016b).

\footnotetext{
${ }^{11}$ Governance of investment and construction of basic plans; and usage of state budget in 2008 for controlling inflation.
} 


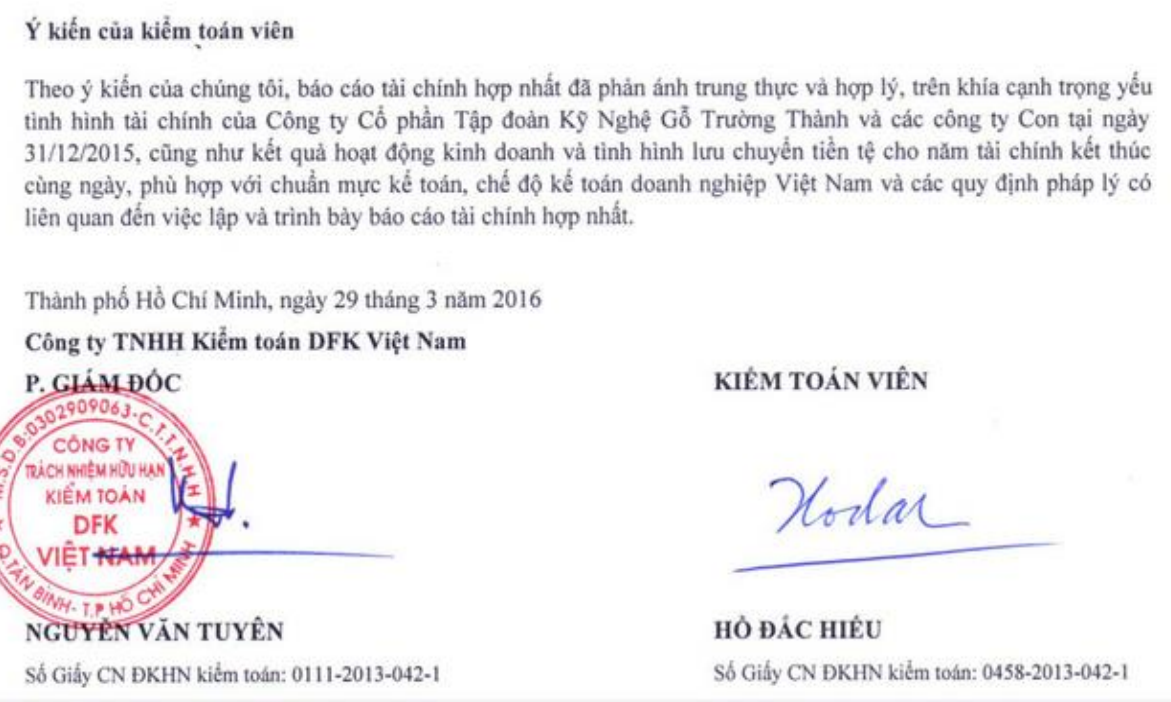

According to the audit report prepared by audit firm DFK and dated 29 March 2016, the consolidated financial statements reflected a true and fair view of the material aspects of TTF and its subsidiaries as at 31 December 2015. In particular, the audit report stated that the income statement and statement of cash flows complied with Vietnamese accounting standards (VAS) and Uniform Accounting System for enterprises (UAS) and other legal documents in relation to the preparation and presentation of the consolidated financial statements.

However, when the international accounting firm Ernst and Young (EY) was appointed to audit TFF's financial statements for the year ended 2016, they found that 980 billion VND (US \$43 million) of inventory did not exist. In addition, there were signs of overstating the value of inventory as surety for bank loans. Further, fictitious transactions were created in order to increase revenue and profit via related party transactions. In addition, TFF's financial statements also failed to disclose an amount of 90 million VND (US \$4million) for which they acted as a surety for another company (DLC) to get a loan at Viet A Bank (Cafef, 2016a). The board of management of TFF had approved 250 billion VND surety for DLC. However, the actual amount that TFF warranted for DLC had not been recorded and no related documents were kept by TFF's accounting department (Kiem toan Pro, 2016a). After these issues were announced, TFF's share price dropped from 43,600 VND (US\$2) to 8,100 VND (US\$0.37) (Cafef, 2017). Disgruntled investors inquired about the legal responsibility of DFK and the Deputy Head of the Department of Accounting and Auditing Policy (a department of MOF), Mr Trinh Duc Vinh, responded:

DFK only audited the consolidated financial statements of TFF for the years ending in 2015 and prior, so any issues that happened in the financial year ended in 2016 had nothing to do with the DFK. The corporation is responsible for preparing financial statements and submitting related documents to auditors. Auditors are not police investigators to check if documents are real or fake. Instead, they only give their opinion based on documents submitted to them and audit evidence and following audit procedure. Therefore, if a corporation is being deliberately misleading, auditors would become a victim. (Cafef, 2016c)

The comments from the Government authority were a big disappointment to investors and the general public who suffered a huge loss for trusting the professionalism of the gatekeepers. Interestingly, a year after the event, no legal action has been taken and/or announced in the media. 
These two of many recent accounting scandals in Vietnam highlight the importance of professional regulators and auditors as gatekeepers to protect the public interest and investors. However, the case of Vinashin indicates that both Government and its agencies had failed to detect the misconduct from the beginning and provide effective supervision over the company's operations, as suggested by the reformulated version of public interest theory. As a major SEG, Vinashin continues its existence. However, the concern persists as to whether it is operating in the public interest - e.g., taxpayers - or group interest as suggested by capture theory. The case of TTF indicates the lack of professional scepticism of auditors or the potential collusion of the auditors and the corporation. Such incidents raised concerns among the public and investors about the reliability of the audited financial statements. Overly driven by private interest, it would be a challenge to act for the public interest. The involvement of EY accounting firm suggests that the public and investors are in great need of more professional and ethical conduct from auditors.

FVA is a controversial measurement, which exposes the high risk of corporate illegalities if private interests are driving the applications. In other words, it demands an intensive level of supervision from regulators and auditors to protect the public interest. The findings below reflect perspectives of standard setters and professional auditors about the feasibility and challenges of adopting FVA in the context of Vietnam.

\section{Adoption of fair value concept - a challenge for regulators}

The commitment of the Vietnamese government towards IAS/IFRS adoption is manifested by the issuance of the Accounting Law 2015, which permits the revaluation of assets and liabilities in accordance with fair value. It defines fair value as the price appropriate to market price that would be received for sale of an asset or paid to transfer a liability at the measurement date. According to Paragraph 1, Article 6 of this law, assets and liabilities are initially recognised at cost. Subsequent to initial recognition, those assets and liabilities whose values frequently fluctuate following market prices and can be reliably measured shall be stated at fair value at the end of the financial reporting period. This is a fundamental difference between this law and the Accounting Law 2003, which provides that assets are stated at cost and an accounting entity is not allowed to revalue its assets unless otherwise stipulated by other laws and regulations.

The issuance of Accounting Law 2015 is considered a milestone for Vietnam in its transition to IFRS as it allows fair value related accounting standards to be issued such as financial instruments, fixed assets and investment properties. Currently, there are no VAS equivalent to 16 IFRS and IAS, even though there are significant variations between some VAS and IAS/IFRS. In the absence of a VAS equivalent to IAS 32 and 39, IFRS 9 and IFRS 13 on financial instruments, Circular 210 states: "Guiding the application of international accounting standards on presentation of financial statements and disclosures of financial instruments" issued in 2009 does not provide any instructions for the assessment and recognition of fair value of financial assets and liabilities. The legal barrier (Accounting Law 2003 does not allow fair value accounting) has delayed the process of harmonization towards IFRS. Whether such a delay is considered good or bad for the sake of public interest is the primary focus of this study.

As a rules-based centrally planned economy, the fair value concept did not make sense to members of Vietnam's National Assembly who typically have no accounting background and therefore the process of getting the Accounting Law 2015 approved was difficult. A senior regulatory official in the DAAP shared his views:

The National Assembly was alerted that the Accounting Law 2003 allowed application of the cost model only, and this was causing accounting standards to lag behind the 
standards of other countries. The fair value concept was a major concern and challenge for most members of the National Assembly because it allowed too much discretion that corporations could manipulate for tax avoidance (REG, 2).

The law is the highest legal document that provides legal backing for subsequent guidance of accounting practice. The VAS have not been updated because FVA was not allowed in Accounting Law 2003. Empowering managers with high discretion appears be too difficult for members of the National Assembly to accept and is contradictory to the typical institutional setting of Vietnam. Earnings management is perceived to be increasing for various purposes, including tax avoidance. Speaking at a Standing Committee of the National Assembly, the Chairman of a Committee of National Securities, Mr Vo Trong Viet, lamented that auditing and corruption are two parallel lines that never cross each other. Although State auditors have made considerable progress in tackling misconduct in State corporations, there still exists many controversial issues concerning the general public that auditors failed to address (Kiem toan Pro, 2016b). Referring to the case of Vinashin, Mr Vo further stated:

More than 10 groups of State inspectorates and State auditors assessed misconduct in Vinashin but nothing was found. After that, an investigation was started by police investigators and so many issues were uncovered. So, what is the responsibility of auditors? (Kiem toan Pro, 2016b, p. paragraph 4) ${ }^{12}$

The government official indicates that corruption or bribing is a 'sad but true phenomenon' inherent in the country's business environment that challenges the professional ethics, scepticism and independence of auditors and State authorities. In such an environment, even truly and fairly prepared financial statements could also become suspicious. Thus, the concern about FVA raised by the National Assembly seems to be valid. A senior regulator disclosed:

The risk of applying fair value is huge. Thus, at the first instance, the National Assembly did not approve the Financial Instruments and Fair Value standards. In order to explain to government officials on how FVA works in practice, many workshops and seminars were organised with the support of accounting experts from the Big 4 and Western professional bodies. Finally, they approved Accounting Law 2015, which came into being (REG, 2).

This excerpt indicates the substantial support the State and its agencies received from the Big4 firms and professional accounting associations. Great efforts made by those key actors suggest that they all attempt to develop a 'best' accounting practice that will serve decision makers and the general public. Since the country is transitioning from a centrally planned to a market economy, acceptance of a certain level of risk seems to be unavoidable. A Big 4 partner shared his experience of being involved in clarifying the fair value concept to regulators:

When referring to fair value to other departments within MOF, they tend to be very cautious of this concept, as they believe that it leaves room for manipulations and we cannot control it. We [Big 4] have to explain to them that even though we may not be able to control it, we still have to leave the market to decide. We cannot prohibit it just because we cannot control it (PB4, 4).

The Big 4 accounting firms may support the adoption of Western principles, particularly the fair value concept, because it may be in their own interests (as reliable valuation service providers) as well as their clients' interests. However, the support of the Big 4 accounting firms for the adoption of FVA may not necessarily be in the public's best interest.

${ }^{12}$ Source that was orginally in Vietnamese has been translated to English by the author. 
The accounting law has changed but the role of the MOF as a key accounting standard setter remains unchanged under the law. In particular, the DAAP (a department in the MOF) will take on the next challenge, i.e., updating the fair value related standards and preparing detailed guidance on FVA and updates of the rule-based systems (UAS). Due to the complexities and risks associated with applying FVA, PwC (2016) has provided advice that "enterprises should wait for the guidance of the MOF on the implementation of Accounting Law 2015, to have specific guidance" (p.2). A senior regulator in the DAAP stated:

Our 26 standards were prepared following the old IAS and they are rather obsolete. The primary difference between the VAS and IFRS is the concept of fair value. The issuance of the Accounting Law 2015 is a good commencement for the application of fair value (REG, 1).

The VAS have not been updated since its last issuance in 2006 because the fair value concept is not allowed under Accounting Law 2003. It is one of the main causes of disparity between national accounting systems: VAS (principle-based standards) and UAS (rule-based system). Challenges associated with the adoption of FVA that two key regulators in the DAAP revealed are:

Fair value is a difficult concept. It is a challenge for State authorities to control potential manipulations. We need adequate infrastructure; reliable valuation firms; and a good market economy, for fair value to be transparently applied (REG, 2).

Given the fair value concept and its related standards are derived from advanced capital markets where supporting infrastructure has been well developed, importation of this perceived risky approach is a big step to take on due to the underdeveloped valuation system of a transitioning economy. The inefficacy of these matters suggests a high risk of corporate fraudulent activities by using regulatory loopholes. This concern is further highlighted:

For fair value concept to be applied, we need many factors, e.g. determinations of fair value; present value; and current cost. In addition, our financial market and workforce must be well developed. However, at the moment, our market and its information systems are inadequately functioning. For instance: in the banking market, we have to use an overseas market to determine Derivatives, e.g. hedging, because we do not have the market (REG, 1)

Both regulators in the DAAP disclosed many impediments and concerns in adopting IAS/IFRS, especially FVA, due to the inefficiencies in reporting infrastructure and a lack of skilled personnel. Transitioning to a market economy with a socialist orientation compels Vietnam to harmonise to the international accounting standards. Acceptance and implementation of these standards, particularly such a controversial Western principle-based accounting concept as FVA, in a long-standing rule-based economy presents an array of doubts, confusions, and challenges.

\section{Challenges and appropriateness of FVA: Perceptions of auditors}

Different from regulators who were predominantly concerned with potential illegalities, auditors seem to have a more rational response to FVA by signalling the necessity of this new accounting measurement for Vietnam's overall convergence to IAS/IFRS. However, having noted that, they still expressed great concerns over potential misconducts that FVA could bring about in the current context. 
The accounting community has long been using a rule-based uniform accounting system as described in the background section. They expect more detailed instructions via circulars, as an audit partner of a $2^{\text {nd }}$ tier firm commented:

From a practical perspective, we [the accounting profession] have been so familiar with a rule-based system and practitioners always rely on legal guiding documents (circulars). Every time we audit our client's financial report, if we do not agree with any points, they always ask "what legal document mentions that". This approach has become a common practice here in Vietnam. Initiative by practitioners in Vietnam is rather weak as they are not keen on judgments and these impact on the quality of their financial reports $\left(2^{\text {nd }} P, 9\right)$.

The excerpt from the auditor highlights that accountants tend to use accounting regulations (circulars) as a shield for their accounting treatments regardless of whether such instructions are appropriate. By all means, despite regulatory loopholes (if any), compliance with the prescriptions granted companies legitimacy while it hinders auditors from challenging their clients. A Big 4 partner shares this concern: "Application of fair value has a great impact upon accounting systems in Vietnam as there is a high risk of "creativity, cook the books"" (PB4, 5). Another partner adds: "Analysts and investors tend to rely on financial reports for analysis and they are often not cognisant of any traps of frauds inherent in these figures" $\left(2{ }^{\text {nd }} P, 9\right)$. Further to the points that the two partners raised above, there has been a major concern about the reliability of financial reports. The case of Vinashin and Truong Thanh Furniture Corporation are two exemplars of risks that investors and public would bear even before FVA could be legally permitted. Further risks of FVA are revealed:

We do not have databases or reliable sources of information for measuring fair value. Every company comes up with different values and some of them respond to the demands of their clients. In these cases, the valuation fee is based on a portion of the valuation increment $\left(2^{\text {nd }} \mathrm{P}, 10\right)$.

The excerpt reveals a practice in which valuers and companies collude to mislead investors and the general public. In addition, valuers have an incentive to overvalue assets because the valuation fee increases proportionately with the valuation increment. Another partner commented:

We have a legal framework allowing for the fair value concept to be applied. However, as you know in our system, we require further detailed instructions of what fair value is and how to measure it, what rate is considered the effective rate or discount rate etc. Further, we do not have a bond market; there is not a free market of products; and skills of professional valuers are inferior $\left(2^{\text {nd }} \mathrm{P}, 9\right)$.

The centrally planned system has resulted in an ingrained rule-based approach. This is problematic when adopting principle-based standards because the national accounting and reporting infrastructure, accounting regulators and accountants do not seem to be well prepared to take on the challenges of a system that allows considerable discretion and judgment. Besides the aforementioned impediments, a partner also commented on the influence of tax authorities on recognising fair-value based figures.

Even though the new law has permitted application of fair value, its implementation is a real challenge for we do not have an official database for its valuation. The tax department may not accept the proposed fair value made by business. However, they might accept a fair value amount provided by professional valuers. (PB4, 7) 
Comments from the partner of a Big 4 firm highlight the important role of valuers and valuation firms for the fair value concept to be efficiently applied. He also implies that the tax authority might accept a valuation made by professional valuers if they are independent and reliable. A partner of a second-tier accounting firm believes that the accounting field is not ready for FVA. He stated:

I think it is not the right time for fair value application. It is a challenge because we have not had a database, which is used for valuation. Moreover, users do not have sufficient knowledge to understand and apply the fair value concept $\left(2^{\text {nd }} \mathrm{P}, 8\right)$.

Lack of professional skills of accountants and unavailability of a reliable valuation database are two main concerns for the FVA to be applied. Having noted that, a partner of a Big Four expressed a positive sentiment:

We have not adopted IAS 36 but the concept of impairment of assets or valuation decrements of assets are applied in other IASs. For instance: Valuation of inventory with recognition of a loss. Such a concept also exists in our VAS. For financial instruments IAS 39, impairment is called a valuation loss in Vietnam. For tangible fixed assets, we apply IAS 36 (PB4, 3).

This interviewee claimed that the valuation process is not entirely new to the accounting system in Vietnam and application of FVA would not be too challenging. In addition, a senior partner of a Big 4 firm remarks that a valuer's biggest challenge is the valuation of intangible assets $(\mathrm{PB} 4,6)$. Further to an array of impediments that the above excerpt raises, the cost of hiring a professional valuer is also an issue. This may result in resistance to FVA and maintenance of the historical cost notion $\left(2{ }^{\text {nd }} \mathrm{P}, 8\right)$. If justifiable, these two concepts seem to be both acceptable as a common practice (PB4, 6 and 4). Generally, implementation of FVA in a transitioning economy requires a substantial level of guidance and supervision. In addition, all participants highlighted the importance of having professional valuers, standards for valuation and adequate infrastructure for FVA to be transparently applied.

In summary, the increasing demand for FVA application in financial reporting has given much pressure on State authorities and auditors in a transitioning economy like Vietnam. They have little faith in the feasibility and reliability of FVA to be transparently applied in the current stage given the valuation profession and capital market are still at their embryonic stage of development, exposing risk of high earnings manipulation. In addition, the contemporary legal system, ownership structures and institutional environment seem to be less supporting of FVA in the business environment in Vietnam.

\section{Discussion}

This study explores the suitability and challenges that an emerging economy is facing in adopting and implementing fair value accounting (FVA). With a long history of a centrally planned economy in which SOEs were dominant and received exclusive State protection, economic reforms, despite a reduced number of SOEs, did not seem to reduce the State's influence and the dependence of SOEs and/or privatised SOEs on such longstanding protection. Further to the work of Gainsborough (2009), the case of Vinashin provides insights into the inefficiency of SOE's operations, poor corporate governance and collusion between the top managers and the chief accountant. The findings of this study support Vu's (2012) concern about the lack of disclosure and transparency in the business environment in Vietnam, which heightens the risk of manipulations using FVA. 
Despite privileges that SOEs receive from the government, many SOEs did not perform well and misconduct and frauds have been reported. The Government and its agencies are presumably "public servants" (Levine and Forrence, 1990) responsible for protecting the public interest and social welfare (Peirson and Ramsay, 1983; Perera, 1989). The case of Vinashin reveals that the Government sought to prioritise the public interest by providing financial support to Vinashin so that they could meet their obligations to 70,000 employees. Without such a timely intervention, an enormous number of employees might have been made redundant. The State, on the one hand, enforced compliance with the legal guidance, but on the other hand, undermined it to meet "private interest". By implying their guarantee, the government encouraged banks to provide more loans to Vinashin without going through a proper credit risk assessment and making a provision for such high-risk loans. Prescriptions of State regulators offer legitimacy to commercial banks (e.g., Oceanbank) to hide their bad debts. In fact, it is "illegitimate" because the welfare of stakeholders is not taken into consideration. This finding is supportive of Barlev and Haddad's (2003) conclusions.

Was Vinashin too big to fail? Or was there any "private interest" of those officeholders? The answers "yes" and "yes" are offered in response to these two questions. The case of Vinashin threatened the stability of the national economy and its international credit rating (public interest). Thus, it could reasonably explain the government's action. The second "yes" was given due to the probable influence of officeholders' private interests (Walker, 1987; Chalmers et al., 2012). Indeed, it is hard to be convinced that no misconduct or illegality was found after 11 inspections and audits. It is arguable that regulators and auditors, as key gatekeepers, overlooked or were over-confident because the government backed this corporation. Its 'celebrity' status helped it to conceal its illegal actions. Being an 'adorable child' of the government, pressure to meet the expectations had also instigated the deviance. This supports the findings by Gabbioneta et al. (2013) that institutional context affects the illegality of companies. Further to the work of Gabbionete et al. (2013), this study argues that the Criminal Law 1999 Article 285 could be a major catalyst for growing incentives for earnings management. Such a law may threaten management not to disclose losses in the value of assets, albeit it might be caused by normal business operations. Moreover, political effects and collusive practice have unfortunately become a 'practical norm' in this setting, which is like a 'cancer' creating decay in public trust and investors' confidence, including the World Bank. As discussed in the background section, Vinashin is just one of many fraudulent cases discovered in SOEs lately.

Beside the State authorities, auditors also play a key role in protecting the public interest through their professionalism. The case of Truong Thanh Furniture Corporation (TTF) again reveals concerns over earnings manipulation and the reliability of financial statements. It highlights that auditors, for example the DFK audit firm, might have compromised the public interest in favour of their private interests, as suggested by Peltzman (1976). The issue of auditors' independence expressed through the case of TTF may not be new to relevance literature of developed countries. However, it is a major issue in emerging economies like Vietnam as it is transitioning to a market economy from State control and the public's trust/reliance are therefore shifting from State authorities to auditors. The primary challenges and risks exposed in these two cases are the concerns that the ethics or independence of regulators and auditors could be compromised.

In this vulnerable context, most of the interviewees, including regulators and auditors, expressed great concern about FVA implementation. The resistance of the National Assembly to the introduction of the fair value concept in the first place was understandable and it was fuelled by concerns of earnings manipulation for tax avoidance and deceiving investors. These 
worries are derived from the under-developed valuation and reporting infrastructure, unskilled valuers, absence of valuation standards, and potential collusions occurring in valuation processes. Moreover, the risk of applying this debateable concept is accentuated when the State agencies that are expected to provide detailed guidance via circulars to the practitioners, are themselves not competent in FVA's implications. In this rule-based institutional environment, the incompetency of standard setters and underdevelopment of supportive infrastructure constitute a favourable environment for misconduct to 'legally' occur by applying legal guidance. Further to prior studies (He et al., 2012; Kumarasiri and Fisher, 2011; Peng and Bewley, 2010), this study argues that the application of FVA in Vietnam, given the several challenges identified, could create 'legitimate regulatory loopholes' that gate-keepers may not be able to detect. While FVA is probably too risky for a fragile country like Vietnam at this stage (Nissanke and Thorbecke, 2006), this study proffers some suggestions that may pave way to FVA implementation and mitigate potential fraudulent conducts in the heterogeneous context of Vietnam.

- overcoming the specified shortcomings;

- providing extensive detailed rules of permissible inputs and selections of pricing options;

- enhancing transparency by making extensive disclosure requirements mandatory;

- executing harsh penalties/sanctions on gate-keepers; and

- setting tone at the top

While the current study supports suggestions of Peng and Bewley (2010) and Benston et al., (2006), it highlights that State regulators continue to juggle public and private interests in the issuance and enforcement of regulations; and that auditors might cave into the demands of deceitful managers.

\section{Conclusion}

The debate on FVA application continues to be a heated topic, especially in the context of developing economies. Accounting is a product of its environment. Adoption of a perceived high quality standard does not necessarily benefit the adoptive countries, and may become harmful when national idiosyncrasies are not taken into consideration. The case of Vietnam reveals a complex transitioning setting in which State intervention is notoriously a norm and regulatory processes can be captured by the personal interests of officeholders. Given the several challenges identified, this study suggests that the contemporary business environment in Vietnam is less favourable for adopting FVA, at least until these weaknesses are effectively tackled. The cases of Vinashin and Truong Thanh Furniture Corporation cast doubt on the independence of auditors, resulting in fraudulent financial statements deceiving investors and the general public. Although this study does not investigate the independence or professionalism of auditors in Vietnam, these concerns have fuelled debates on FVA in the literature, with Enron and Arthur Andersen being a notorious case (Benston, 2006). This is an area that is worthy of future research.

This study contributes to the growing concerns about the suitability of FVA in developing countries. It demonstrates that the risk of manipulations is a major concern causing resistance to the introduction of FVA, particularly when the government and its agencies may not be capable of detecting or controlling the issue. This study further argues that in a State-controlled institutional environment, political factors might create a more complex environment for FVA to be effectively applied. The study also suggests that the complexity of the business 
environment in Vietnam - including the domination of State interventions, the existence of SOEs and the State's interest in equitized SOEs, as well as an intricate web of laws - is not conducive to FVA being transparently applied. Given various challenges and inherent 'FVA fatal' weaknesses, implementation of FVA may create 'legitimate regulatory loopholes' in this uniform system, especially when regulators have limited knowledge of FVA and auditors' independence is being questioned.

As with all empirical studies, this research has its limitations. The key limitation of this study is the findings are based on a low number of interviews. Since Vietnam is still at a very early stage of FVA implementation, interviews with key regulators who are standard setters, as well as senior audit partners of the Big-Four and second-tier firms who work closely with the standard setters, may provide further important insights to this topic. 


\section{References:}

Aboody, D., Barth, M. E. and Kasznik, R. (1999), "Revaluations of fixed assets and future firm performance", Journal of Accounting and Economics, Vol. 26, pp.149-178.

Al-Khadash, H. A. and Abdullatif, M. (2009), "Consequences of fair value accounting for financial instruments in the developing countries: The case of the banking sector in Jordan", Journal of Business Administration, Vol. 5 No. 4, pp. 533-551.

Al-Yaseen, B. S. and Al-Khadash, H. A. (2011), "Risk relevance of fair value income measures under IAS 39 and IAS 40”, Journal of Accounting in Emerging Economies, Vol. 1 No. 1, pp. 9-32.

Anderson-Gough, F., Grey, C. and Robson, K. (2005), "Helping them to forget..": The organisational embedding of gender relations in public audit firms", Accounting, Organizations and Society, Vol. 30 No. 5, pp. 469-490.

Ball, R. (2006), "International Financial Reporting Standards (IFRS): Pros and cons for investors", Accounting and Business Research, Vol. 36(sup1), pp. 5-27.

Barlev, B. and Haddad, J. R. (2003), "Fair value accounting and the management of the firm", Critical Perspectives on Accounting, Vol. 14 No. 4, pp. 383-415.

Barlev, B. and Haddad, J. R. (2007a), "Harmonisation, comparability and fair value accounting Journal of Accounting”, Auditing and Finance, Vol. 22 No. 3, pp. 493-509.

Barlev, B. and Haddad, J. R. (2007b), "Harmonization, comparability, and fair value accounting", Journal of Accounting, Auditing and Finance, Vol. 22 No. 3, pp. 493-509.

Barth, M. E. (1994), "Fair value accounting: Evidence from investment securities and the market valuation of banks", The Accounting Review, Vol. 69, pp. 1-25.

Barth, M. E., Beaver, W. and Landsman, W. R. (1996), "Value relevance of banks' fair value disclosures under SFAS 107", The Accounting Review, Vol. 71, pp. 513-537.

Barth, M. E. and Clinch, G. (1996), "International differences in accounting standards: Evidence from UK, Australian, and Canadian firms", Contemporary Accounting Research, Vol. 13 No. 1, pp. 135-170.

Barth, M. E., Landsman, W. R. and Wahlen, J. M. (1995), "Fair value accounting: effects on banks' earnings volatility, regulatory capital, and value of contractual cashflows", Journal of Banking \& Finance, Vol. 19, pp. 577-605.

Benston, G. J. (2006), "Fair-value accounting: A cautionary tale from Enron", Journal of Accounting and Public Policy, Vol. 25 No. 4, pp. 465-484.

Benston, G. J., Bromwich, M. and Wagenhofer, A. (2006), "Principles - versus rules-based accounting standards: The FASB's standard setting strategy", Abacus, Vol. 42 No. 2, pp.165-188.

Beresford, M. (2008), "Doi Moi in review: The challenges of building market socialism in Vietnam", Journal of Contemporary Asia, Vol. 38 No. 2, pp.221-243.

Burchell, S., Clubb, C. and Hopwood, A. G. (1985), "Accounting in its social context: Towards a history of value added in the United Kingdom”, Accounting, Organizations and Society, Vol. 10 No. 4, pp.381-413.

Bureau of Economic and Business Affairs. (2018). "Investment Climate Statements for 2018", available

at:

https://www.state.gov/e/eb/rls/othr/ics/investmentclimatestatements/\#wrapper (accessed 4 September, 2018).

Cafef. (2016a). "Gỗ Trường Thành: Tiếp tục phát hiện một số sai lệch nghiêm trọng, chuyển cơ quan điều tra xem xét", available at: http://cafef.vn/go-truong-thanh-tiep-tuc-phat-hienmot-so-sai-lech-nghiem-trong-chuyen-co-quan-dieu-tra-xem-xet20160825133249574.chn (accessed 18 August, 2017). 
Cafef. (2016b). "Kiểm kê thiếu hụt gần 1.000 tỷ tại Gỗ Trường Thành: Trách nhiệm của công ty kiểm toán DFK Việt Nam thế nào?", available at: http://cafef.vn/kiem-ke-thieu-hut-gan1000-ty-tai-go-truong-thanh-trach-nhiem-cua-cong-ty-kiem-toan-dfk-viet-nam-the-nao20160802224133432.chn (accessed 18 August, 2017).

Cafef. (2016c). "Bộ Tài chính nói gì về trách nhiệm của Kiểm toán DFK trong scandal Gỗ Trường Thành?", available at: http://cafef.vn/bo-tai-chinh-noi-gi-ve-trach-nhiem-cuakiem-toan-dfk-trong-scandal-go-truong-thanh-20160821232924452.ch (accessed 2 October, 2017).

Cafef. (2017). "Đã tròn 1 năm sau biến cố kiểm kê thiếu 1.000 tỷ đồng hàng tồn kho khiến Gỗ Trường Thành (TTF) giảm sàn 24 phiên liên tiếp", available at: http://cafef.vn/da-tron-1nam-sau-bien-co-kiem-ke-thieu-1000-ty-dong-hang-ton-kho-khien-go-truong-thanh-ttfgiam-san-24-phien-lien-tiep-201707190924567.chn (accessed 2 October, 2017).

Cafef. (2018). "Phát hiện doanh nghiệp nhà nước sai phạm gần 346.000 tỷ đồng", available at: http://cafef.vn/phat-hien-doanh-nghiep-nha-nuoc-sai-pham-gan-346000-ty-dong20180514070453334.chn (accessed 3 September, 2018).

Cairns, D., Massoudi, D., Taplin, R. and Tarca, A. (2011), "IFRS fair value measurement and accounting policy choice in the United Kingdom and Australia", The British Accounting Review, Vol. 43 No. 1, pp.1-21.

CENSOGOR. (2017). "Anti-corruption in doing business: An assessment from enterprises perspective", available at https://towardstransparency.vn/wpcontent/uploads/2017/05/4.-BUSINESS-CASE-REPORT_Executive-

Summary_ENG.pdf.

Chalmers, K., Godfrey, J. M., and Lynch, B. (2012), "Regulatory theory insights into the past, present and future of general purpose water accounting standard setting", Accounting, Auditing and Accountability Journal, Vol. 25 No. 6, pp.1001-1024.

Choi, F. S. S. and Mueller, G. G. (1992), International Accounting, Prentice Hall, New Jersey.

$\mathrm{Chu}, \mathrm{T}$. (2004), Accounting changes in a transition economy: the case of Vietnam (PhD Thesis), University of Wollongong.

Collett, P. H., Godfrey, J. M. and Hrasky, S. (2001), "International harmonization: cautions from the Australian experience", Accounting Horizons, Vol. 15 No. 2, pp.171-182.

Dan Tri. (2018a). "Cơ quan điều tra đề nghị xử lý hành chính đối với ông Trần Bắc Hà", available at https://dantri.com.vn/phap-luat/co-quan-dieu-tra-de-nghi-xu-ly-hanhchinh-doi-voi-ong-tran-bac-ha-20180721121556906.htm (accessed 4 September, 2018).

Dan Tri. (2018b). "Phạm Công Danh bị tuyên phạt 20 năm, Trầm Bê lãnh 4 năm tù", available at https://dantri.com.vn/phap-luat/pham-cong-danh-bi-tuyen-phat-20-nam-tram-belanh-4-nam-tu-20180806160420892.htm (accessed 4 September, 2018).

Dau Tu Chung Khoan. (2017). "Ủy ban Chứng khoán sẽ "mạnh tay" với báo cáo tài chính sai phạm", available at: http://tinnhanhchungkhoan.vn/chung-khoan/uy-ban-chung-khoan-semanh-tay-voi-bao-cao-tai-chinh-sai-pham-178336.html (accessed 16 August, 2017).

Downs, A. (1957), An economic theory of democracy, Harper and Row, New York.

Downs, A. (1967), Inside bureaucracy, Little, Brown Boston.

Elad, C. (2007), "Fair value accounting and fair value: An analysis of the role of International Accounting Standard No. 41 in social conflict", Socio-Economic Review, Vol. 5 No. 4 , pp.755-777.

Elad, C. (2015), "The development of accounting in Franc Zone countries in Africa", The International Journal of Accounting, Vol. 50, pp.75-100.

Elleuch, S. H. and Taktak, N. B. (2015), "Earnings management and evolution of the banking regulation: The case of Tunisian banks following the IMF recommendations", Journal of Accounting in Emerging Economies, Vol. 5 No. 2, pp.150-169. 
Ezzamel, M., Xiao, J. Z. and Pan, A. (2007), "Political ideology and accounting regulation in China", Accounting, Organizations and Society, Vol. 32 No.7/8, pp.669-700.

Fischer, P. E. and Verrecchia, R. E. (2000), "Reporting bias", The Accounting Review, Vol. 75 No. 2, pp.229-245.

Flick, U. (2014), An introduction to Qualitative Research, $5^{\text {th }}$ Edition, Sage Publications.

Gabbioneta, C., Greenwood, R., Mazzola, P., and Minoja, M. (2013), "The influence of the institutional context on corporate illegality", Accounting, Organizations and Society, Vol. 38 No. 6, pp.484-504.

Gaffikin, M. (2005), "Regulation as accounting theory. University of Wollongong. Working paper", available http://ro.uow.edu.au/cgi/viewcontent.cgi?article=1049\&context=accfinwp (accessed 5 November, 2017).

Gainsborough, M. (2009), On the borders of state power: frontiers in the Greater Mekong subregion, Routledge, Oxford.

Hakkala, K. and Kokko, A. (2007), "The State and the private sector in Vietnam", available at http://swopec.hhs.se/eijswp/papers/eijswp0236.pdf (accessed 13 February, 2017).

He, X., Wong, T. J. and Young, D. (2012), "Challenges for implementation of fair value accounting in emerging markets: Evidence from China", Contemporary Accounting Research, Vol. 29 No. 2, pp.538-562.

Hodder, L., Hopkins, P. and Schipper, K. (2013), "Fair value measurement in financial reporting", Foundations and Trends in Accounting, Vol.8 No. 3/4, pp.143-270.

Hopper, T., Lassou, P. and Soobaroyen, T. (2016), "Globalisation, accounting and developing countries", Critical Perspectives on Accounting.

Hopwood, A. G. (1983), "On trying to study accounting in the contexts in which it operates", Accounting, Organizations and Society, Vol. 8 No. 2/3, pp.287-305.

IAS Plus. (2017). "IFRS 13 Fair value measurement", available at: https://www.iasplus.com/en/standards/ifrs/ifrs13 (accessed 16 February, 2017).

International Accounting Standard Board (IASB). (2006), "Fair value measurements" (discussion paper), available at http://www.ifrs.org/Current-Projects/IASB-Projects/FairValue-Measurement/Pages/Fair-Value-Measurement.aspx (accessed 16 February, 2017).

Jeffries, I. (2010), Contemporary Vietnam: A guide to economic and political development, Routledge, London.

Jermakowicz, E. K. (2004), "Effects of adoption of IFRS in Belgium: The evidence from BEL20 companies", Accounting in Europe, pp.51-70.

Jermakowicz, E. K. and Gornik-Tomaszewski, S. (2006), "Implementing IFRS from the perspective of EU publicly traded companies", Journal of Accounting, Auditing and Taxation, Vol. 15, pp.170-196.

Kiem toan Pro. (2016a), "Gỗ Trường Thành (TTF): Tiếp tục phát hiện một số sai lệch nghiêm trọng, chuyển cơ quan điều tra xem xét", available at: http://www.kiemtoanpro.com/gotruong-thanh-ttf-tiep-tuc-phat-hien-mot-so-sai-lech-nghiem-trong-chuyen-co-quan-dieutra-xem-xet/ (accessed 5 September, 2017).

Kiem toan Pro. (2016b), "Kiểm toán bay trên trời, tham nhũng đi dưới đất nên ít gặp", available at: http://www.kiemtoanpro.com/kiem-toan-bay-tren-troi-tham-nhung-di-duoi-dat-nen-itgap/ (accessed 1 August, 2017).

Kumarasiri, J. and Fisher, R. (2011), “Auditors' perceptions of fair value accounting: Developing country evidence", International Journal of Auditing, Vol. 15, pp.66-87.

Lao dong. (2010), "Kiểm toán Nhà nước chưa từng kiểm toán Vinashin", available at: https://laodong.vn/chinh-tri/kiem-toan-nha-nuoc-chua-tung-kiem-toan-vinashin-127.bld (accessed 5 September, 2017). 
Larson, R. K. and Street, D. L. (2004), "Convergence with IFRS in an expanding Europe: Progress and obstacles identified by large accounting firms' survey", Journal of International Accounting, Auditing and Taxation, Vol. 13 No. 2, pp.89-119.

Laux, C. and Leuz, C. (2009), "The crisis of fair-value accounting: Making sense of the recent debate", Accounting, Organizations and Society, Vol. 34 No. 6/7, pp.826-834.

Levine, M. E. and Forrence, J. L. (1990), "Regulatory capture, public interest, and the public agenda: Toward a synthesis". Journal of Law, Economics, \& Organization, Vol.6 (Special Issue: Organization of political Institutions Conference, April 1990 ), pp.167-198.

McDonough, R. P. and Shakespeare, C. M. (2015), "Fair value measurement capabilities, discussion and the perceived reliability of fair value estimates: A discussion of Bhat and Ryan (2015)", Accounting, Organizations and Society, Vol. 46, pp.96-99.

Miller, P. (1994), Accounting as social and institutional practice: an introduction. In A. G. Hopwood and P. Miller (Eds.), Accounting as a Social and Institutional Practice, Cambridge University Press, Cambridge.

Mitnick, B. M. (1980), The political economy of regulation: Creating, designing, and removing regulatory forms, Columbia University Press, New York.

Narayan, F. B. and Godden, T. (2000), Financial management and government issues in Vietnam, Asian Development Bank (Phillippines).

Nguyen, C. P. and Nguyen, T. D. K. (2012), "International harmonisation and national particularities of accounting: Recent accounting development in Vietnam", Journal of Accounting and Organizational Change, Vol. 8 No. 3, pp.431-451.

Nguyen, C. P. and Richard, J. (2011), "Economic Transition and Accounting System Reform in Vietnam", European Accounting Review, Vol. 20 No. 4, pp.693-725.

Nguyen, L., Hooper, K. and Sinclair, R. (2013), "Conservatism versus change in the Vietnamese accounting field”, Corporate Ownership and Control Journal, Vol. 11 No. 1, pp.471-482.

Nissanke, M. and Thorbecke, E. (2006), "Channels and policy debate in the GlobalisationInequality-Poverty nexus", World Development, Vol. 34 No. 8, pp.1338-1360.

Patton, M. Q. (2002), Qualitative Research and Evaluation Methods (3rd ed.), Sage Publications, Thousand Oaks.

PCAOB (2000), "Panel of Audit Effectiveness, Report and Recommendations: Chapter 3Earnings management and fraud", available at: https://pcaobus.org/News/Events/Documents/09082004_SAGMeeting/Fraud_Attachmen t_1.pdf (accessed 8 August 2017).

Pearson, J. (2018). "Vietnam set to make key ruling on country's biggest-ever fraud case", available at https://www.reuters.com/article/us-vietnam-malaysia-fraud/vietnam-setto-make-key-ruling-on-countrys-biggest-ever-fraud-case-idUSKCN1IT1B2 (accessed 4 September, 2018).

Peirson, G. and Ramsay, A. L. (1983), "A review of the regulation of financial reporting in Australia", Companies and Securities Law Journal, Vol. 1, pp.286-300.

Peltzman, S. (1976), "Toward a more general theory of regulation", Journal of Law and Economics, Vol. 19 No. 2, pp. 211-240.

Peng, S. and Bewley, K. (2010), "Adaptability to fair value accounting in an emerging economy: A case study of China's IFRS convergence", Accounting, Auditing \& Accountability Journal, Vol. 23 No. 8, pp.982-1011.

Perera, H. (1989), "Accounting in developing countries: A case for localised uniformity", British Accounting Review, Vol. 21, pp.141-158.

Posner, B. (1974), "Theories of economic regulation", Bell Journal of Economics and Management Science, Vol. 5, pp.335-358. 
Qu, X. and Zhang, G. (2015), "Value relevance of earnings and book value over the institutional transition in China: The suitability of fair value accounitng in this emerging market", The International Journal of Accounting, Vol. 50, pp.195-223.

Rubin, J. H. and Rubin, S. I. (2005), Qualitative Interviewing: The art of hearing data, Sage, London.

Taylor, K. W. (1983). The birth of Vietnam, University of California Press, Berkeley, CA.

Thanh nien. (2010), "Chính phủ "mổ xẻ" các sai phạm của Vinashin", available at: http://thanhnien.vn/thoi-su/chinh-phu-mo-xe-cac-sai-pham-cua-vinashin-144224.html (accessed 5 September, 2017).

The Guardian. (2011), "Massively indebted Vietnamese shipbuilder misses payment", available at: https://www.theguardian.com/world/2011/jan/04/vietnam-financial-crisis (accessed 17 August, 2017).

Tower, G. (1993), "A public accountability model of accounting regulation", British Accounting Review, Vol. 25, pp.61-85.

Truong Thanh. (2017), "Welcome to our company", available at: https://www.truongthanh.com/index.php? $\mathrm{m}=$ main\& $\mathrm{f}=$ home\&lang=en $\quad$ (accessed 5 September, 2017).

Tuoi Tre. (2010), "Vinashin: cơ chế "độc nhất vô nhị", available at: http://tuoitre.vn/tin/chinhtri-xa-hoi/20100707/vinashin-co-che-doc-nhat-vo-nhi/388731.html (accessed 17 August, 2017).

Tuoi Tre. (2017), "Khởi tố nguyên chủ tịch hội đồng quản trị Vinashin", available at: http://tuoitre.vn/khoi-to-nguyen-chu-tich-hoi-dong-quan-tri-vinashin-1376590.htm (accessed 5 September, 2017).

Van Arkadie, B. (2003), Vietnam - A Transition Tiger? Canberra: Asia Pacific Press.

Vietnam Investment Review. (2017a). "Three contractors blacklisted by World Bank for fraud", available at http://www.vir.com.vn/three-contractors-blacklisted-by-worldbank-for-fraud-52007.html (accessed 3 September, 2018).

Vietnam Investment Review. (2017b). "Two contractors punished for fraud in World Bankfunded road project", available at http://www.vir.com.vn/two-contractors-punishedfor-fraud-in-world-bank-funded-road-project.html (accessed 3 September, 2018).

Vietnamese National Assembly. (2003). "Luật số 03/2003/QH11 của Quốc hội: Luat ke toan", (Accounting Laws), available at http://vanban.chinhphu.vn/portal/page/portal/chinhphu/hethongvanban?class_id=1\&mod $\mathrm{e}=$ detail\&document_id=93587 (accessed 5 September, 2017).

Vietnamnet. (2012), "Nợ xấu ngân hàng được giấu như thế nào?", available at: http://vietnamnet.vn/vn/kinh-doanh/no-xau-ngan-hang-duoc-giau-nhu-the-nao89422.html (accessed 7 September, 2017).

Vnexpress. (2017), "2 executives get death sentence in Vietnam's major shipping scandal", available at: http://e.vnexpress.net/news/news/2-executives-get-death-sentence-invietnam-s-major-shipping-scandal-3545420.html (accessed 7 September 2017).

Vnexpress. (2018). "Another Vietnamese banker named for violations linked to massive banking fraud case", available at https://e.vnexpress.net/news/business/anothervietnamese-banker-named-for-violations-linked-to-massive-banking-fraud-case3758186.html (accessed 3 September, 2018).

Vu, K. B. A. H. (2012), Determinants of voluntary disclosure for Vietnamese listed firms. Curtin University.

Walker, R. G. (1987), “Australia's ASRB. A case study of political activity and regulatory capture", Accounting and Business Research, Vol. 17 No. 6/7, pp.269-286. 
World Bank. (2006), Corporate governance country assessment: Vietnam. Report on the observance of standards and codes. Vietnam: World Bank.

World Bank. (2012), "Market economy for a middle-income Vietnam", available at: http://documents.worldbank.org/curated/en/495721468327934602/pdf/659800AR00PUB L0elopment0Report02012.pdf (accessed 5 September 2017).

World Bank. (2015). "World Bank Debars SFC Vietnam Investment Development for Environment Corporation for Sanctionable Misconduct Relating to Two Projects in Vietnam", available at http://www.worldbank.org/en/news/pressrelease/2015/12/18/world-bank-debars-vietnam-investment-sanctionable-misconduct (accessed 3 September, 2018). 